\title{
INCLUSIVE EDUCATION OF SEN CHILDREN IN NURSERY: ANXIETY AND SELF-EFFICACY OF CHILDCARE PROFESSIONALS
}

\author{
Marielle Bruyninckx, Dimitri Cauchie, Mélanie Dutrieux, \& Maud Regnier \\ Human Development and Data Processing Department, University of Mons (Belgium)
}

\begin{abstract}
The will to recognize and to take into account the needs and the skills of Special Education Need children in order to give them perspectives of an inclusive education cursus is already possible in nurseries. Inclusive education of such babies can be enriching for everyone; but it can also become a source of stress and anxiety for the nursery professionals. It challenges all their working procedures, the usual standards and reference marks but also the perceptions and conceptions they acquired over time about children care. So they have to adjust the way they work with children and accept to be more flexible. (Bazier \& Mercier, 2009; Béclin \& De Pauw, 2014; Camus \& Rogier, 2012; Garcia, 2014; Hendrix, 2013). This research focuses on workers of two public nurseries who welcome Special Education Need babies in the French speaking part of Belgium. We met eleven nursery nurses, a director and the parents of two SEN children. We used semi directive interviews with each of them. We also used three additional tools with the nursery nurses: the Spielberger's State-Trait Anxiety Inventory (STAI-Y) (1990 trad), the Follenfant and Meyer's working self-efficacy scale (2003) and the drawing of a nursery typical day. Our results show that the type of disability influences the workers conceptions and practice. Investing inclusive education is not so easy for the workers. Various factors influence their feelings and could be approached through specific actions in order to reduce their anxiety (anticipation of the child's reception conditions, better communication between parents and workers, specific training programs, professional support and assistance). Choosing inclusive education must always be carefully and properly thought and care must be taken to constantly improve the working procedures.
\end{abstract}

Keywords: SEN children, municipal nursery, professional childcare, anxiety, work self-efficacy.

\section{Introduction}

The evolution of the concept of disability encourages the development of innovative inclusion projects and a better consideration of the specific needs of individuals. This is particularly true in nurseries that welcome Special Education Need children (SEN). These babies face health issues and/or sensory, motor and/or cognitive disabilities (Garcia, 2014; Vandenbroeck et al., 2010). It is therefore essential to encourage their stimulation and to promote their socialization, but the challenges of inclusive education are numerous and concern all stakeholders. For all the nursery professionals, these new situations are often a source of uncertainty and anxiety that can lead to a decrease in self-confidence and to a feeling of helplessness. (Bazier \& Mercier, 2009; Béclin \& De Pauw, 2014; Camus \& Rogier, 2012; Georlette-De Bruyne \& Vandevoorde, 2014; Hendrix, 2013).

In the French speaking part of Belgium, several legal texts specify the conditions under which the approval of the early childhood facilities is issued. The inspection of nurseries and the granting of approvals are carried out by the "Office de la Naissance et de l'Enfance" (ONE), a public institution under the supervision of the French Speaking Community Government. According to the law, a nursery is an "early childhood facility designed to accommodate children aged zero to 36 months with a staff of qualified professionals". It also specifies that the childcare facility must be attentive to the specific needs of each child and must promote respect for their differences in order to facilitate their integration. The early childhood facilities are therefore part of a global political effort to include children with disabilities in ordinary environments. It is also expected that the ONE provides specific support to the staff involved in these situations and liaise with specialized external services (AGCF, 2003).

\section{Methods and instrumentation}

The aim of our research was to study how the actors of early childhood facilities understand and analyzed their personal and/or professional reality when they have to welcome SEN children. The research 
is part of an exploratory approach, whose subject has been little developed in the scientific literature. We focused on workers of two public nurseries who welcome SEN babies. These daycare facilities are organized by the Public Social Action Center of the City of Mons and are included in the legal framework presented above. Since 2013, they have been particularly concerned with ensuring a quality inclusive welcome for babies with specific needs. Our research questions were: what are the preconceptions of the social stakeholders about SEN babies and inclusion? What are the consequences on their everyday practices? What are the favorable factors than can improve the anticipation of an inclusive welcome project? In order to answer these questions, we met 11 nursery nurses, a director and the parents of two SEN children. We used semi directive interviews with each of them. We also used three additional tools with the nursery nurses: the Spielberger's State-Trait Anxiety Inventory (STAI-Y) (1990 trad), the Follenfant and Meyer's working self-efficacy scale (2003) and the drawing of a nursery typical day.

\section{Main results}

\subsection{The semi directive interviews}

The purpose of the semi-structured interviews was to bring out the meaning given by the actors to the inclusive childcare experience. The sessions were organized on the basis of an interview guide focused on various themes (Berthier, 2012). Our cross-sectional analysis highlights that our childcare professionals have a preconception about the inclusive approach that is essentially based on the need to adapt their professional practices and their professional environment, to better meet the needs of children because they consider integration into the peer group as an essential factor of inclusion. On the other hand, only few professionals highlight the importance of equality of treatment between children and collaboration with parents. These preconceptions vary essentially according to the nature and the severity of the child's disability because, according to them, it influences the necessary environmental adaptation. Our results highlight an important difference between the experiences lived by the professionals of the two studied structures. In the first one, all of the nursery stakeholders and the director describe their experience in a positive way and talk about a climate of trust with the parents. In the second, the testimonies are more negative: all express the exhaustion engendered by the simultaneous reception of three SEN babies; many express a feeling of loneliness and frustration and relate anxiety-provoking situations. All the parents we met described, for their part, a mostly positive experience and a good relationship with the team. They felt supported and think that the professionals had real interest for their child. They appreciate the efforts they made to ensure the quality of the stay. Overall, the involvement of the staff during the setup of the project favors a positive and serene experience. Only some nursery stakeholders said that they were not really associated with the decision and that they were forced to accept to work with the SEN babies.

\subsection{The Spielberger's State-Trait Anxiety Inventory (STAI-Y, 1990)}

Spielberger's Inventory of State-Trait Anxiety Form Y (1983), translated by Bruchon-Schweitzer and Paulhan (1990), was used to evaluate the possible state of anxiety of the nursery caregivers facing an inclusive care project, compared to their usual anxiety. All of our subjects obtained fairly equivalent scores, which underline, for each of the two dimensions, a level of anxiety that is "low" or even "very low" (see Table 1). In addition, we can also note that our subjects show less specific anxiety in their professional situation (State Anxiety) than in their usual life (Trait Anxiety).

Table 1. Results at the Spielberger's State-Trait Anxiety Inventory.

\begin{tabular}{|c|c|c|c|c|}
\hline & Minimum & Maximum & Mean (std dev) & Interpretation \\
\hline Trait Anxiety & 27 & 40 & $\mathbf{3 2 . 7 5 ( 5 . 4 5 )}$ & Very low \\
\hline State Anxiety & 23 & 34 & $\mathbf{2 7 . 7 5 ( 3 . 9 6 )}$ & Very low \\
\hline
\end{tabular}

\subsection{The Follenfant and Meyer's working self-efficacy scale (2003)}

The Follenfant and Meyer's Working Self-Efficiency Scale (2003) allows an assessment of a person's belief in his ability to act, to perform a mission in a professional context. Our results show that, overall, the assessment that nursery nurses make of their self-efficacy at work is fairly average (32.11, see Table 2).

Table 2. Results at the Follenfant and Meyer's working self-efficacy scale.

\begin{tabular}{|c|c|c|c|}
\hline & Minimum & Maximum & Mean (std dev) \\
\hline Nursery A & 33 & 36 & $34.20(1.17)$ \\
\hline Nursery B & 25 & 26 & $29.50(4.39)$ \\
\hline All nurses & $/$ & $/$ & $\mathbf{3 2 . 1 1}(3.84)$ \\
\hline
\end{tabular}


The results of the subjects of the nursery B (29.50) are lower than those obtained in the nursery A (34.20). This could be explained by a weaker belief in their ability to cope with a professional situation that differs from their normal working environment. The variability of their individual results is also stronger (4.39 vs 1.17). These values reflect the differences found in the cross-sectional analysis of interviews and drawings.

\subsection{The drawing of a nursery typical day}

The drawings of "a typical day at the nursery" gave us data about subjective representation that the professionals had about welcoming a SEN baby. In nursery A, three of them represented a playful moment. Another illustrated a morning welcome scene with all the babies. It is interesting to note that only one drawn the parents and the team. The majority of the caregivers drew a group of children: in half of the cases, the SEN baby is integrated into the group and no distinguishing sign makes it possible to perceive his/her disability; in the other half, the professionals represented themselves apart, or without the other children, therefore underlying a special relationship with the SEN baby. In the nursery B, only one professional drew the three SEN babies simultaneously; others only one or two. A child is almost always absent from the productions (he presents behavior challenges difficult to manage for the team). All the illustrations give an image of a comfortable and playful place of welcome.

\section{Conclusions}

The inclusive welcome of a SEN baby within early childhood facilities is not easy to organize. Our results however show a real motivation of the professionals but also the importance of identifying the factors that could undercut their engagement. Before welcoming the child, it is necessary to organize meetings with the parents and to plan a period of familiarization with the project. The training of the team will also allow the actors to enter serenely in the process. These elements increase the self-confidence of the professionals and secure the parents. Improving the professionals' skills, through support of specialized services, is also important because an inclusive approach can always be a source of questioning, stress or even anxiety. Choosing inclusive education must always be carefully and properly thought and prepared. The process must be supported by external specialists. It must also contain continuous training sessions in order to constantly improve the working procedures quality and to reduce the workers' anxiety.

\section{References}

Arrêté du Gouvernement de la Communauté française $[\mathrm{AGCF}]$ portant réglementation générale des milieux d'accueil (27 février 2003). Moniteur belge, 21 mai 2003, pp. 27557-27600.

Bazier, G., \& Mercier, M. (2009). La situation de l'aide précoce et de l'accueil de la petite enfance en situation de handicap en Communauté française de Belgique. Contraste, 2(31-32), 155-180.

Béclin, G., \& De Pauw, L. (2014). Synthèse des rapports d'activités 2013: Projets d'initiative spécifique. Accueil de la petite enfance. Charleroi: Agence pour une Vie de Qualité.

Berthier, N. (2012). Les techniques d'enquête en sciences sociales : Méthodes et exercices corrigés. Paris: Armand Colin.

Bruchon-Schweitzer, M., \& Paulhan, I. (1993). Adaptation française de L'Inventaire d'Anxiété Etat-Trait forme Y (STAI-Y) de Spielberger. Paris: Les Editions du Centre de Psychologie Appliquée.

Camus, P., \& Rogier, G. (2012). Recommandations pour soutenir le travail des agents ONE: soutenir les enfants en situation de handicap et leur famille dans tous les lieux de vie. Namur: Office de la Naissance et de l'Enfance.

Follenfant, A., \& Meyer, T. (2003). Pratiques déclarées, sentiment d'avoir appris et auto-efficacité au travail: Résultats de l'enquête quantitative par questionnaires. In P. Carré \& O. Charbonnier, Les apprentissages professionnels informels (pp. 185-246). Paris: L'Harmattan.

Garcia, S. (2014). Un projet d'accueil pour le jeune enfant en situation de handicap. Empan, 1(93), 12-17.

Georlette-De Bruyne, M., \& Vandevoorde, M. (2013). L'accueil de l'enfant à besoins spécifiques. In J. Ternest, L'inclusion des enfants en situation de handicap dans les milieux d'accueil de la petite enfance: Guide de formation à l'attention des professionnels de la petite enfance 0-3 ans (pp. 39-54). Bruxelles: File asbl.

Hendrix, M. (2013). Les enfants à besoins spécifiques. In J. Ternest, L'inclusion des enfants en situation de handicap dans les milieux d'accueil de la petite enfance: Guide de formation à l'attention des professionnels de la petite enfance 0-3 ans. (pp. 21-38). Bruxelles: File asbl.

Vandenbroeck, M., Boudry, C., De Brabandere, K., Vens, N., \& De Smedt, E. (2010). L'inclusion: L'inclusion des enfants ayant des besoins spécifiques. Gand : Vernieuwing in de Basisvoorzieningen voor Jonge Kinderen [VBJK]. 